\title{
Precarious Worlds
}

\section{Danish Colonialism and World Literature}

\author{
Mads Anders Baggesgaard* \\ Aarhus University \\ madsbaggesgaard@cc.au.dk
}

\begin{abstract}
The role played by Denmark in the triangular slave trade and colonial chattel slavery is rarely part of the tale told about Danish literature. This article investigates the reflections of this history in Denmark and discusses how this particular colonial history and its relationship to literature can be understood on the basis of readings of three texts from Denmark and its former colony St. Thomas. The central thesis is that exactly because of the peripheral and precarious nature of the Danish colonial endeavour in relation to larger colonial systems, it may actually be possible to reflect on sides of the colonial history that is often left out of sight.
\end{abstract}

\section{Keywords}

colonial literature - slavery - Danish literature - world literature

Danish colonial history and our role in the transatlantic slave trade are rarely part of the story told about Danish literature. Foreign commentators may be excused for this neglect. After all, the Danish role in the slave trade is dwarfed by the role of the major empires. It is true that Denmark had trading stations in Ghana and colonised the three Caribbean islands of St. Thomas, St. Croix and

* The research leading to this article has been made possible by the generous support of the Velux Foundation to the research project Reading Slavery-Comparative Studies of the Literature of the Transatlantic Slave Trade. I would also like to thank my co-members in this project Frits Andersen, Jakob Ladegaard, Jonas Ross Kjærgård, Karen-Margrethe Lindskov Simonsen and Sine Jensen Smed for lively discussions and Mads Rosendahl Thomsen for years of debates on the pasts and futures of world literature. 
St. John. But even so, the part played by Denmark as a colonial power hardly compares to the large colonial systems organised by France, Britain, Spain, Portugal and the Netherlands.

In a Danish context this silence is, however, more problematic. Denmark may have played a smaller part than other countries, but Danish colonial history is in no way anecdotal. Denmark may not compare to the major colonial powers, but it was the seventh-largest slave-trading nation and more than 100,000 slaves crossed the Atlantic on ships outfitted in Copenhagen. St. Thomas' main city and port, Charlotte Amalie, was the second-largest city in the Danish kingdom in the nineteenth century, and a significant part of the Danish wealth accrued during this period was generated through colonial trade dependent upon slave labour.

The end of this part of colonial history, however, will have its centennial in 2017. What was once the Danish colony Dansk Vestindien (The Danish West Indies) has been the Us Virgin Islands for 100 years, after having been sold for $\$ 25$ million and transferred to the USA on 31 March 1917. As a result, the common history between the two places has to a certain extent been wiped out, written out of the national history or perhaps simply forgotten. No formal relation exists between the two places and an important question on this occasion is of course how we should understand this neglected relationship, and how and to what extent the colonial past influences the understanding of the position of Danish literature in relation to a larger world. Few would doubt that the colonial trajectories of the British, French and Spanish empires have a real and still existing impact on the position of literature written in these languages on a global scene. This impact is of course the general question addressed by postcolonial literature studies. But the same link is a lot more difficult to establish when talking about the impact of colonial history on the literatures of smaller colonial powers like the Denmark, Germany and Sweden. This does not mean that these stories are not significant. On the contrary, this article claims that the study of smaller colonial powers and their literatures does in fact add important aspects to our understanding of the colonial system and the role of literature and text for this understanding. The precarious nature of the Danish colonial system, and of the governing of the island of St. Thomas in particular, makes it a very interesting case for understanding the logics of the colonial world and the role played by the worlds of literature within it. In the following, I sketch out three linked arguments that will serve to discuss this underlying question. First, I look briefly at the trajectory of the Danish relationship to its colonies in order to argue for this precariousness. Second, I look at two literary reflections of the relationship between colony and homeland, arguing that the precariousness of the relationship challenges 
the ideas we hold of the position of literature-some of which we term World Literature-in the imperial order. And finally I will touch upon the position of slavery in relation to the first two points.

\section{Denmark and the Colonial Past}

It is clear that the colonial past has been debated far less in Denmark than in other countries with a similar history, and anthropologist Karen Fog Olwig even suggests that "in the mental enclave of Danish West Indian history, ideologies that are no longer acceptable can still flourish freely" (Olwig 218; see also A. Andersen). But even though it is often stated that Denmark has forgotten its colonial history, this is not entirely accurate. Throughout the twentieth century the story of the Danish part in colonial slavery has been told by a number of writers, most notably Thorkild Hansen in his ambitious trilogy Slavernes kyst, Slavernes skibe and Slavernes øer (1967-70, translated by Kari Dako as Coast of Slaves, Ships of Slaves and Islands of Slaves, 2002-5), where on the basis of documentary evidence he reconstructs the three parts of what he describes as "the drama of slavery" in Ghana, on the ships and in the Caribbean. In the last few years the discussion seems to have heated up with artists, filmmakers and writers engaging with the material, most recently in works such as Jeanette Ehlers' Whip it Good and Say it loud!, Daniel Dencik's recent film Guldkysten (The Gold Coast) and Mich Vraa's historical novel Haabet (The Hope), which all draw attention to this particular part of Danish history not only by demanding a recognition of guilt in the form of an official excuse, but also by reflecting on the ways in which traces of colonialism and colonial racism persist in Danish society today.

Even though these discussions are on the table today, they have appeared much later than in other countries, and there is still a sense of reluctance with regard to taking responsibility. In fact the unwillingness to acknowledge Danish guilt is in itself a central part of the history of Denmark as a colonial power. In 1792, Denmark became the first nation to ban the transatlantic slave trade, and the King's resolution resulted in the performance of a number of plays in the following years, with slaves appearing on stage in order to laud the benevolence and humanity of the King (i.e. Pram; Thaarup; Høegh-Guldberg). However, the truth behind the decision was a lot less humanitarian, as the ban was in fact only to take effect from 1803, and plans were in place to both intensify the import of slaves in the intervening ten-year period as well as the "breeding" of slaves in the colonies in order to obtain a sustainable population (see e.g. Oxholm 27-36). In the first half of the nineteenth century, when 
abolition was the talk of the town in London, Paris and Washington, slavery and abolition were hardly debated in Copenhagen, and the abolition of slavery in the Danish colonies in $\mathbf{1 8 4 8}$ was more of a reaction to the French abolition that same year than the result of a home-grown idea. In fact, the much praised liberation of the slaves by Governor Peter von Scholten is seen by historians today as a mere strategy to quell a slave rebellion occasioned by the abolition in the French colonies. If we look to the Danish literary tradition, slavery and the colonies are rarely mentioned before 1900. Two texts stand out: Henrik Hertz's 1833 novella, Den Frifarvede (The Free-Coloured), and Hans Christian Andersen's 1840 play, Mulatten (The Mulatto), which was an adaptation of the French 1838 novella Les Épaves by Madame Charles Reybaud (see also Sollors 173-87). In both cases, the texts deal with the repercussions of the Haitian revolution of 1791-1804, as part of a now well-described canon of European texts trying to integrate the scenario of slaves freeing themselves into discussions about liberty and freedom within Europe (Daut; Onana). The period after the sale of the Danish West Indian Islands saw the only real effort to write literature about the colonies in the form of three rather sentimental novels written by the returned expat Lucie Hørlyk (Riis). Traces of colonial history are thus late and scarce in Danish literature, especially when compared to the vivid interpretations known from French, English and even German literature.

There are of course a number of reasons for this relative indifference to Danish colonial history. The Danish islands were sold a century ago, so Denmark has not seen the waves of immigration from former colonies experienced by other colonial powers through the twentieth century. There is thus no significant group of descendants of slaves to insist on the retention of the memory of slavery and the importance of the culture of the enslaved. However, this silence is not only the result of historical distance. Even during the colonial period, the Danish colonies were not placed centrally in the national Danish consciousness, but were by and large considered foreign. A telling example is the 1903 short children's book, Glade Barndomsdage i Vestindien (Happy Childhood Days in the West Indies). Here Ingeborg Vollquartz, who had just returned from a four-year stay in the colonies, introduces the exotic wonder that was the Danish West Indies to Danish children, describing the exotic landscapes, plants, turtles etc., and the strange experience of Christmas in a tropical climate. However, one central concern was how to relate to the two protagonists as Danish:

But even though the boys were Danish-yes, the youngest was in truth born over there- but he was of course Danish anyway—and both had 


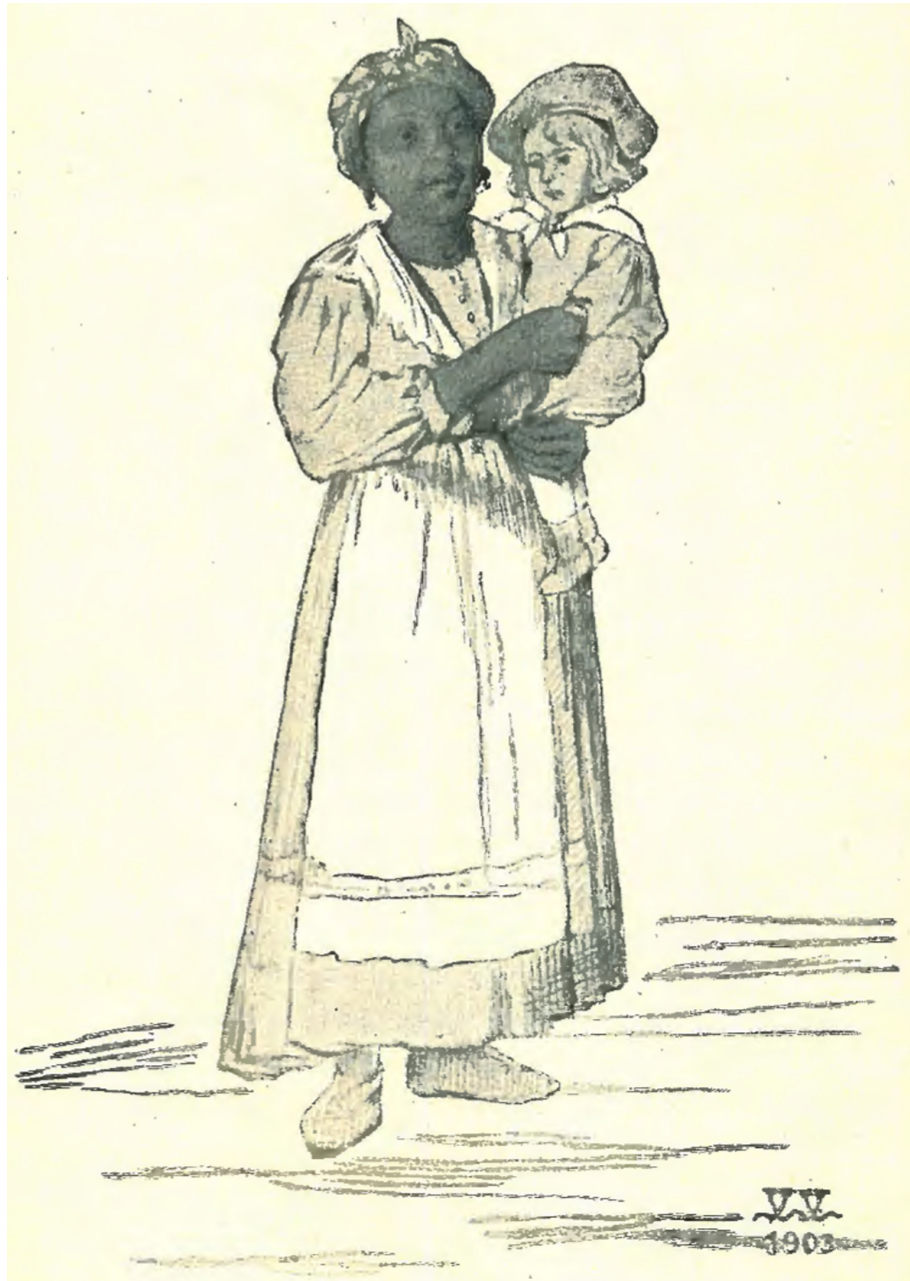

FIGURE 1 The nanny Consuela holding Aage (Vollquartz 7)

good Danish names-the older one was called Jørgen, the younger Aage - they did not speak Danish—no they spoke English, they learned it from their black nanny, for she did not know a single Danish word. ${ }^{1}$ VOLLQUARTZ 6

1 "Men uagtet Drengene var danske — ja, den yngste var rigtignok født derovre-men derfor var han jo alligevel dansk — og begge havde de gode danske Navne-den ældste hed Jørgen, den yngste Aage—saa var det alligevel ikke dansk de talte—nej, de talte engelsk, det lærte de af deres sorte Barnepige, for hun kunde ikke et eneste dansk Ord." 
The good Danish names guarantee the sense of national belonging even though the setting is clearly not like the one recognised as Danish by the reader. The foreignness of the colonies is a common trope in colonial literature, but it becomes even more central here simply because the Danish colonies were never very Danish. Very few of the planters in the Danish colonies were from Denmark: in St. Thomas they were predominantly Dutch, and in St. Croix predominantly English, despite a campaign to enlist Danes to the new colony after the purchase of the island from the French in 1733. Danish was thus never the main language on the islands, but merely an administrative one. And everyday commerce and talk was conducted first in a Dutch creole (known today as Virgin Island Creole), and later on in English, which became the primary language of a multitude of different languages present in the so-called Danish colonies.

\section{Colonial Images of Denmark}

The distance between Denmark and its colonial possessions was also felt in the colonies. In the utopian novel Time and I, or Looking Forward, published in 1902, Adolph Sixto-a black businessman and a central figure in the cultural and political life of the island in the first decades of the new century-laments the view of the islands held by the Danes:

"It was believed," said I, "that the Mother Country entertained but little hope for her Colonies, as they were very expensive to her, and that they could not be self supporting; that there was an opinion among the Danes relative to these Islands and their inhabitants, which was not very gratifying. Although St. Thomas could boast of a high class of civilization and culture, with institutions worthy of any European city, it was considered by many in Denmark to be an African town, still in a primitive state of civilization."

SIXTO 24

Despite this devastating critique, the book is essentially a plea to remain under Danish rule at a historical moment when both independence and a transfer to American rule were being debated. In the book, these discussions are reflected through the establishment of a peculiar narrative arrangement. Time and $I$ is structured as a dialogue between two men. The protagonist "I", an inhabitant of the island in 1899, goes for a walk in the countryside only to fall asleep. As he does so, however, things start changing: "I dreamt that I found myself trans- 


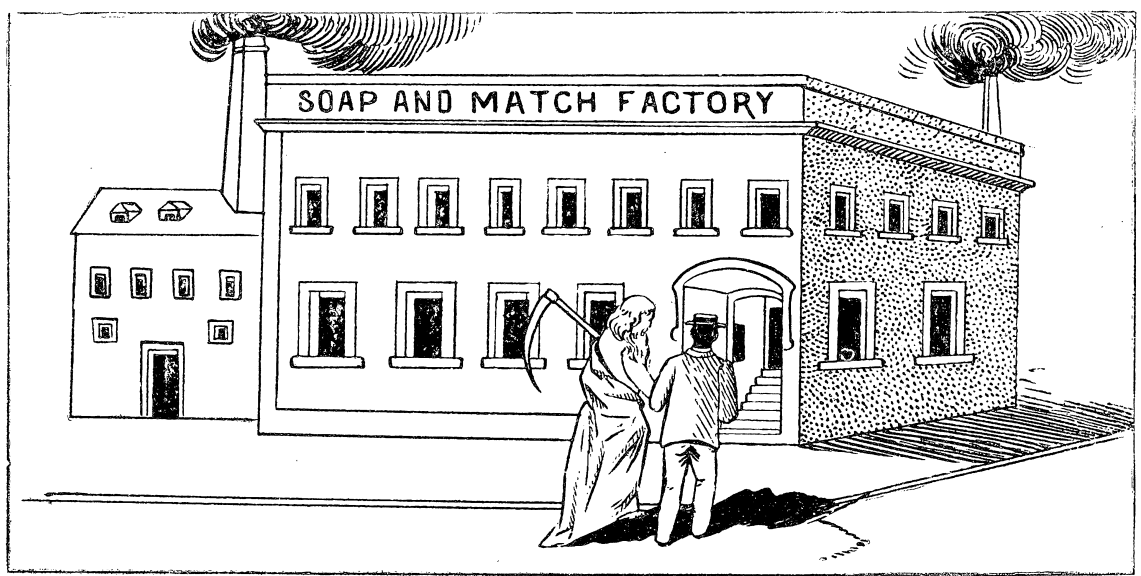

OLR WALK LED US TO THE CO-OPERATIVE SOAP ANI) MATCH FACTORY.

FIGURE 2 "Time" and "I" on one of their walks around the islands (Sixto 164)

ported to the hills of an enchanted place where nature's greatness was revealed on every hand." This greatness of nature appears in the form of "luxuriant fields of cane," "smoking chimneys" and "carts loaded with produce" (Sixto 5). As he wakes up he realizes that this is in fact no dream as he is greeted by "Time" an inhabitant of St. Thomas in 1999, a year to which I has been transported in his sleep. Through the rest of the book Time escorts I on walks around the island in order to make him realise the potential of the island, which is still under Danish rule 100 years into the future.

Taking its cue from Edward Bellamy's Looking Backward (1888), which inspired a wave of hundreds of utopian novels over the next decades (Roemer 1-15), Sixto's book is an attempt to formulate a political vision for the island through the literary imagination. The book is in constant discussion with colonial descriptions of St. Thomas as a barren island, unfit for production and a burden to the Danish state. St. Thomas was the first crown jewel amongst Danish colonies, colonised in 1666; but already in the middle of the eighteenth century agriculture had started to become unsustainable due to erosion and poor management, and in 1733 St. Croix was purchased from the French in order to provide farmland. St. Croix was larger, flatter and much more amenable, and soon became the main focus for the Danish administrators. The two forts Frederiksted and Christiansted on St. Croix became the ports of choice for commandeered Danish ships and the main trading place for incoming slaves and outgoing sugar (Dookhan 126-8; Brøndsted III 63-64).

On the other hand, in the opinion of local planters and traders St. Thomas was left to itself and neglected by the colonial power in Copenhagen. As a result, 
in 1764 the King had no choice but to open up the island's main port in Charlotte Amalie as a free port for trade amongst the Caribbean islands. This was a success. Helped along by Danish neutrality in the Seven Years' War and the American Revolutionary War, free trade made St. Thomas one of the busiest ports of the Caribbean (Brøndsted II 302-12). In the course of the first half of the nineteenth century the town developed into a small, cosmopolitan community of traders, enslaved people, free-coloured storekeepers (Hall 144), Moravian missionaries, Sephardic Jews (Cohen), exiles from the political upheavals in Haiti, Mexico and elsewhere (e.g. Firmin), as well as writers and artists from all over the Caribbean, such as the painters Ėmile Pissarro and Frits Melbye, and the novelist Émeric Bergeaud, who wrote his famous novel Stella living in the Haitian exile community in the part of Charlotte Amalie to this day known as Frenchtown. In 1859 the British novelist Anthony Trollope describes the place without any enthusiasm in his first travel narrative, The West Indies and the Spanish Main: "It is a depôt for cigars, light dresses, brandy, boots, and Eau de Cologne. Many men therefore of many nations go thither to make money and they do make it" (235). Trollope dislikes the island's "Hispano-Dano-NiggeryYankee-doodle population" (236) and the linguistic diversity that comes with it: "One hears English, French, German, and Spanish spoken all around one, and apparently it is indifferent which" (239). However, because of the important role St. Thomas plays as an "emporium" for travel between different colonies and colonial systems, it is both in real life and in Trollope's account unavoidable: "As St. Thomas at present exists it is of considerable importance" (235). This is the central paradox of St. Thomas. That it was undoubtedly an international place, a hub in this early phase of globalisation, playing a crucial role in the development from the colonial system to contemporary forms of capital, to which we shall return later. But it was also, as demonstrated by Trollope and despite its modern nature, seen as backwards and uninteresting, dangerous even. It is this duality of a place, which makes it precarious: existing suspended between the certainty of a mercantilist colonial scheme and a burgeoning capitalist order of unknown potential.

This is even more apparent if we look at the position of the island in a Danish context. In this period, Charlotte Amalie became the second-largest city in the Danish empire; but because the main part of its trade did not benefit the Danish crown directly, the island was increasingly seen as a liability due to the lack of income generated here (Dookhan 243-47). A sale of the islands was attempted in $1865^{-68}$, but was ultimately rejected by the Americans after a long process during which the inhabitants of the islands voted overwhelmingly in favour of joining ranks with the Americans (Brøndsted III 67-93; Tansill 78153). In 1901, the tables were turned and a proposed sale was rejected by the 
upper house of the Danish parliament, in part because of a perceived resistance to the sale from inhabitants of the islands (Brøndsted IV 69-79; Tansill 355-58). Both Time and I and Glade Barndomsdage $i$ Vestindien were published in the aftermath of this attempt, contributing to a vibrant debate about the possible futures of Danish colonialism that reached across the Atlantic. In fact, the copy of Time and I that I have consulted is held by the State and University Library in Aarhus, and bears a dedication dated 6 March 1903 to the Danish politician Jacob Frederik Scavenius, who must have received the book as a present when meeting Sixto on a trip to St. Thomas in the spring of the same year, as part of a commission charged with finding a profitable way of keeping the islands in Danish hands (Brøndsted IV 76).

In his book, Sixto, as described, accuses the Danish people of not valuing their colonial possessions, but the blame does not exclusively fall on the side of the Danes. Rather, Time argues, the troubles are caused by the inability of the islanders to take responsibility for the situation. And in this line of thinking, taking responsibility involves taking advantage of the colonial relationship by trusting the Danish will to govern. The fault lies in not trusting the benevolence of the Danes and not taking Denmark and the Danish language seriously as a basis for learning and identity formation: "Even as the language and literature of other nations formed the chief study of their scholars, so should Denmark's have had your considerations" (Sixto 29-30). The shortcomings of St. Thomas are thus fundamentally rooted in the inability to participate in the development of national culture, exemplified through literature and culture in a broader sense. Benedict Anderson is well known for his analysis of the role played by "print-capitalism" in the establishment of national identity as imagined communities (45). And this is exactly what Sixto wishes to achieve with his book: to provide the St. Thomians with a collective sense of purpose in order to create a prosperous society "under the benign rule of Denmark or otherwise" (Sixto v). He finishes his introduction with a passage that emphasizes the link between literary expression, the ability to dream, intellectualism and industriousness:

The dream of the Poet, the Artist and the Scientist have borne fruit of priceless value to the human race. Therefore, my book, are you less justified in relating in dream what you would desire in reality?

To deny you that privilege would be to rob you of your sacred object, which is, that my countrymen may arise, and, by universal and industrial co-operation, create for St. Thomas an everlasting resting place among the industrial and intellectual countries of the world. I wish you life. 
This is a strong statement, and it would be tempting to actually proclaim Time and I to be a St. Thomian littérature mineure, a collective enunciation standing in the precarious space between Danish and American literatures, between the old colonial system and a burgeoning global capitalism (Deleuze and Guattari, 48-49). And this may very well be the case, but the fact remains that the text did not make much of a difference. The attempts to reinvigorate agriculture and industry on the island failed, partly because of the First World War, and in 1917 the sale of the islands was finalised. Sixto's novel did not have a big impact either: it was largely neglected both at home and in a global world of literature, where books printed by the newspaper on the next island rarely make a dent. Bearing this history in mind, Time and I rather refutes the political reading, emphasising instead the unevenness of the literary playing field, following Pascale Casanova's critique of Deleuze and Guattari (Casanova 280-81).

\section{Literary Worlds}

Either way, Sixto's literary attempt meets formidable opponents in the dynamics of colonialism, and maybe the very idea of literature both in itself and as a political tool is part of the problem. The role of literature as an educational tool used to spread an inherently Western conception of culture as modernisation, part of the colonial project, is also well described by, for example, Gayatri Chakravorty Spivak, who analyses how the "liberal education," asked for by Sixto, serves as a crucial proof of access to the white administrative class for people deemed to be of colour (Spivak 164-69). This reading has recently been developed in relation to the questions posed by the emerging discipline, or the revamp of comparative literature, known as world literature by Michael Allan in his In the Shadow of World Literature: Sites of Reading in Colonial Egypt. Taking the study of Egyptian literature as his vantage point, Allan argues that literature, or the modern western conception of literature that underlies concepts of world literature, works through the exclusion of other, traditional textual or literary practices, which are labelled archaic and/or primitive:

There is in the end, no position from which to think outside the moral universe of modernization. To be perceived as tied to an "old system" is to be positioned outside the terms of being recognizably educated — and ultimately outside the terms of being recognizably critical.

ALLAN 73 
Allan's case involves the delinking of the Arab word for "literature" (adab) from traditional narrative forms and a traditional form of cultivation to something aligned with transnational novelistic prose in the process of modernisation in Egypt in the first half of the twentieth century. His example makes the contextual nature of the concept of literature very apparent, with considerable methodological consequences. Before reading the text as a representation, direct or indirect, of a political or cultural reality, we must confront and in fact read "the reading praxis necessary for a text to be recognized as an object of literary analysis" (Allan 7). The Egyptian case is hardly comparable to a place like St. Thomas, which has no traditional forms of narrative to delink. Rather the point is that the same dynamics come into play in relation to a place that is in itself unquestionably modern. In Egypt as in St. Thomas, literature is part of the processes that govern subjectification, and reading the place thus becomes reading the way in which literature functions in that concrete setting, as literature or world literature constitutes a set of reading practices that impose themselves locally in interaction or even struggle with other forms of text.

The conception of world literature suggested by Allan builds on known models in that it not only designates the study of how literature travels the world, but also examines "the contours of a world within which a text comes to be read as literature" (Allan 18). The world of world literature is notoriously hard to pin down. Sometimes it seems to be a smooth globalised space with almost no resistance. At other times, the world and the construction of worlds becomes a task performed by literature on its own from singular perspectives. In between these extremes stands the world as it is: a striated space of uneven development where literature is written, circulated and read.

The Warwick Research Collective (WReC) has pointed to this very schism as the central challenge for a new world literature, seeking a theoretical foundation for understanding "World-literature as the literary registration of modernity under the sign of combined and uneven development" (WReC 17). And in the inaugural issue of the Journal of World Literature, Karen Thornber makes a similar claim, albeit using a different vocabulary: "With several notable exceptions, world literature scholarship has not fully addressed the relationship between world literature and such global problems as human rights abuses, trauma, poverty, slavery, environmental degradation, and health and disease" (115). In both cases the authors argue for an engagement with common problems, or more precisely that literature offers an engagement with these problems and that the discipline of world literature can pick up on these engagements as expressions of communality. In the Warwick version, this can be done through reading for an irrealism that appears globally in very different forms but as responses to a shared, yet unevenly distributed "singular modernity," to 
use Frederic Jameson's term. In Thornber's reflections, direct engagement with "global problems," problems that concern us all, can hopefully be, as she terms it, "ameliorated" when seen through the global prism of world literature.

Both approaches are laudable and important, but they also tend to see literature as something that has a reflective role in relation to a set of global, historical problems. In an article published in the journal Alif, the American comparatist Joseph Slaughter questions the basic assumption that literature is an innocent bystander to globalisation and to the construction of the global problems presented by WReC and Thornber. He claims that the opposite is the case, that literature acts as an important agent of colonial and postcolonial power, establishing and maintaining hierarchies of intellectual and cultural capital, manifested in international trade agreements and copyright rules. His line of thought is close to that of Allan, who highlights the necessity of studying changes in the status of the concept of literature itself, especially within the field of world literature. Slaughter quotes the introduction to the Longman Anthology of World Literature as follows: "Works of world literature engage in a double conversation ... with their culture of origin and with the varied contexts into which they travel away from home" (Slaughter $5^{6-57}$ ). In the adjoining footnote, Slaughter makes an strong claim: "If the 'double conversation' is a defining quality of World Literature, then the foundational texts would seem necessarily to be those produced under conditions of imperialism, diaspora, exile, slavery, and other forms of domination. That is, the subordinated, subaltern voice would seem to be the primary voice of World Literature" (Slaughter 69, n. 13). If world literature is about the circulation of people and texts and the meetings that this circulation makes possible, then surely the central task of this discipline should be to investigate not only the texts that travel easily, as it is most often done, in Slaughters view, but the texts that express the flipside of the process by highlighting not only how literature relates to a "singular modernity" or "global problems" but also how it relates to local problems brought on by imperial forces.

\section{Literary Slavery}

Slaughter's footnote, however, seems slightly at odds with his overall objectives. If the study of world literature should also reflect the ways in which it affirms colonial power structures, then surely it is not only a question of hearing the voices of the subaltern, but also to reflect on the ways in which these voices are used to confirm or challenge the colonial order through literature. Slavery is not only an experience, but also an integral part of the economic system underlying 
the growth of world literature as part of the colonial order. Both texts analysed in this article were produced under conditions of imperialism, but neither can be seen to express subaltern voices. In fact they were written more than half a century after the abolition of slavery. However, one does not have to look far for the topic to come up, as when the protagonists in Glade Barndomsdage $i$ Vestindien are preparing to return to Denmark: "At home you did not need nearly as many servants, because there you could exert yourself. It was only in this hot country that everyone was always on summer vacation-in Denmark everyone had to work" (Vollquartz 27). ${ }^{2}$ This passage clearly displays not only the hypocrisy but also the naturalisation of a racially founded unevenness of the playing field that goes way beyond market shares to the question of who is allowed to write, read and sell literary products.

Slavery is, as highlighted by both Thornber and Slaughter, one of the touchstones for these discussions, a global problem, today and historically, that relates to universal questions of freedom, humanity and property. But also, in the form of transatlantic chattel slavery, a historical phenomenon that served as an important basis for the development of the global capitalist world order with which world literature is undoubtedly and inextricably linked. Slavery is thus key to the question of world literature not only because it underscores fundamental inequalities, but precisely because it links these inequalities to the questions of voice and agency and the material role of literature and text in a globalised world. To put it bluntly, slaves embody the subaltern because they have no voice. Testimonies such as Olaudah Equiano's are in this respect mere exceptions that highlight the millions of untold stories behind them; and literature is overwhelmingly on the wrong side of history, serving as a tool for the establishment and maintenance of the slavery system both through the establishment of slaves as the Other and as part of the system of global documentation set up by the imperial powers (Baucom 225-26).

This is clearly to simplify things. On the one hand, literature played an important part in the development of the very ideals of humanitarianism in the abolition movements, as shown by Lynn Hunt and others. And on the other hand, narrative, literature and textual documentation in general have served as powerful tools in the hands of the enslaved and the formerly enslaved, as shown by Rebecca Scott and Jean M. Hébrard, and as is apparent in the rich literary traditions of the Caribbean and the African diaspora more broadly. As revealed

2 "Derhjemme behøvede man ikke nær saa mange Tjenestefolk, for der kunde man godt selv bestille noget. Det var kun her i dette varme Land, at man allesammen altid holdt Sommerferie-i Danmark maatte alle Mennesker arbejde." 
in our short quote from Vollquartz, slavery is also a repressed underside to the colonial narrative as such, something that also becomes apparent if we look at the title page of another important, earlier St. Thomasian publication, John P. Knox's A Historical Account of St. Thomas, W.I., published in 1852. For more than a century Knox's book was the primary authority on the history of the island. Knox was an American pastor at the St. Thomas Reformed Church, and apart from his historical work he is also known for his encouragement of the young Edward M. Blyden to pursue education in the U.s. and his fruitless efforts to help him gain acceptance at an American university (King 61-62). This is, however, beside the point here. On his title page, Knox lists the elements of the book.

The emphasis is on St. Thomas, with chapters on its progress, commerce, churches and facts such as climate and natural history. However, the book also includes what he terms "incidental notices" of events from the other two islands concerning "slave insurrections in these islands, emancipation and present condition of laboring classes" (title page). The interesting thing is the contrast between these descriptions: St. Thomas is trade and churches, while St. Croix is the seat of production and slavery. St. Thomas is modern, regulated, and describable, whereas the other two islands are the home of the dangerous forces of the enslaved, set to erupt at any time in history. The opposition between St. Croix and St. Thomas has also been remarked upon by visual scholar Nicholas Mirzoeff: "Capitalized trading St Thomas, with its new urban lumpenproletariat, confronted and interfaced with the highly policed cultivation of St Croix" (161). Mirzoeff sees this division not so much as a division between two sides of colonialism, but as a sign of a transformation from an early to a later form of colonialism, in the form of modernity as "the product of the real interpenetration of colony and capital" (165). However, what becomes apparent in Knox is that despite the abolition of slavery, the "old" order of slavery is still very much alive in the form of a fear of insurrection, a fear that was to come to life in the form of the strikes and rebellions that hit St. Croix in 1878 .

What is interesting in this context is that this fear presents itself not only on the title page, but also in the form of a marked shift in narrative modes. The chapters on St. Thomas are factual, boring even, but the description of the insurrections are narratives, conjuring up vivid images: "The serjeant [sic.] had sprung through a window without the walls of the fort, but injuring himself so severely as to be unable to escape, was also murdered .... After murdering Judge Scotman, and placing his head upon a pole, they held a council around his mutilated remains, whether they should kill his daughter, a beautiful child twelve years old" (Knox 72-73). In this way, Knox's descriptions present them- 


\section{A HISTORICAL ACCOUNT}

\section{or \\ Weat Indies \\ S T. TH O M A S, W. I., \\ WITr}

ITS RISE AND PROGRESB IN COMMERCE; MISBIONS AND

CHORCHES; ClIMATE AND ITS ADAPTATION TO INVA-

LIDS; GEOLOGICAL STRUCTURE; NATURAL

HISTORY, AND BOTANY;

ANQ INCIDENTAL NOTICES OF

ST. CROIX AND ST. JOHNS;

GLAVE INGURRECTIONS IN THESE ISLANDS; FMANCIPATION AND PRESENT CONDITION OF LABORING CLASSES.

B Y J O H P. K N O X, PASTOR OF THE RETORMTD DUTCR CHUROE, BT. THONAS, W. I.

NEW YORK :

CHARLES SCRIBNER, 145 NA8SAU STREET.

1852.

F 2105

K74

FIgURE 3 Title page of John P. Knox's A Historical Account of St. Thomas, W.I. 
selves as an eerie counterpart to the dreams presented by Sixto. The literary modes of description are used not to present new visions of the future, but to conjure the ghosts of past crimes in the form of the enslaved. A past that is of course still very much present in their time as the productive and labouring basis for the nascent modernism of St. Thomas. Sixto of course highlights the necessity for the education and culture for the transformation of the formerly enslaved, described as unable to acknowledge the value of work:

Consequently he fled from the cane into the world, a disgusted field labourer and, being incompetent to earn his bread, he dragged himself into a hospital or an asylum, a pauper, and there he died; thus incurring the extra expense for charity which could have been spent for educating him.

SIXTO 66

Both Sixto and Knox thus emphasise St. Thomas as a place in which the relationship between corporeal realities and literary imagination is put to the test. The uncertain status of the Danish colonies is not only about flags and symbols, but a question of how lives are lived and spent in production before and after abolition. Together the stories of Sixto, Vollquartz and Knox emphasise that the colonial space of the Danish West Indies was precarious, a place in which Danes, planters from other parts of the world and freemen like Sixto tried to negotiate their position through literature. It is hard if not impossible to pinpoint a particular use of literature in relation to questions of empire and slavery, but through the cases presented here it is clear that literature serves to investigate possible worlds within the colonial whole.

St. Thomas is undoubtedly placed on the periphery, not so much of the Danish kingdom as on the periphery of the old colonial world as such. But this periphery is also a central and paradigmatic position in a new emerging world order of global capitalism, however transiently. A perfect place, as Michael Allan terms it "to question the borders of world literature" (140).

\section{Works Cited}

Allan, Michael. In the Shadow of World Literature: Sites of Reading in Colonial Egypt. Princeton: Princeton UP, 2016.

Andersen, Astrid Nonbo. "'We Have Reconquered the Islands': Figurations in Public Memories of Slavery and Colonialism in Denmark 1948-2012." International Journal of Politics, Culture, and Society 26 (2013), 57-76. 
Andersen, Hans Christian. Mulatten in Skuespil $I I-1836-1842$. Copenhagen: Det Danske Sprog- og Litteraturselskab \& Gyldendal, 2005, 275-372.

Baucom, Ian. Specters of the Atlantic: Finance Capital, Slavery, and the Philosophy of History. Durham: Duke UP, 2005.

Bergaud, Émeric. Stella. Genève: Éditions Zoé: 2009.

Brøndsted, Johannes (ed.). Vore gamle tropekolonier, 2nd ed. 8 vol. Copenhagen: Fremad, 1966.

Casanova, Pascale. La République mondiale des Lettres. Paris: Seuil, 1999.

Cohen, Judah M. Through the Sands of Time: A History of the Jewish Community of St. Thomas, U.s. Virgin Islands. Waltham: Brandeis UP, 2004.

Daut, Marlene L. Tropics of Haiti: Race and the Literary History of the Haitian Revolution in the Atlantic World, 1789-1865. Liverpool: Liverpool UP, 2015.

Deleuze, Gilles and Félix Guattari. Kafka. Pour une littérature mineure. Paris: Minuit, 1975 .

Dencik, Daniel. Guldkysten (film). Prod. Michael Haslund-Christensen. Denmark/ Ghana/Sweden: Haslund/Dencik Entertainment Aps, 2015.

Dookhan, Isaac. A History of the Virgin Islands of the United States. Epping: Caribbean UP and Bowker Publishing, 1974.

Ehlers, Jeannette. Say it Loud! Copenhagen: Forlaget Nemo, 2016.

Firmin, Anténor. Lettres de Saint-Thomas: Ètudes sociologiques, historiques et littéraires. Paris: V. Giard and E. Brière, 1910.

Green-Pedersen, Svend-Erik. "The Scope and Structure of the Danish Negro Slave Trade." Scandinavian Economic History Review 19:2 (1971), 149-197

Hall, Neville A.T. Slave Society in the Danish West Indies: St. Thomas, St. John and St. Croix. Jamaica: The University of the West Indies Press, 1992.

Hansen, Thorkild. Coast of Slaves. Trans. Kari Dako. Accra: Sub-Saharan Publishers, 2002.

Hansen, Thorkild. Ships of Slaves. Trans. Kari Dako. Accra: Sub-Saharan Publishers, 2003.

Hansen, Thorkild. Islands of Slaves. Trans. Kari Dako. Accra: Sub-Saharan Publishers, 2005 .

Hansen, Thorkild. Slavernes kyst. Copenhagen: Gyldendal, 1967.

Hansen, Thorkild. Slavernes skibe. Copenhagen: Gyldendal, 1968.

Hansen, Thorkild. Slavernes øer. Copenhagen: Gyldendal, 1970.

Hertz, Henrik. De Frifarvede, Fra Kjcerligheds Veie Nytaarsgave 1836. Copenhagen: Dansk Vestindisk Selskab \& Poul Kristensens Forlag, 1998.

Høegh-Guldberg, Frederik. Lise og Peter. Copenhagen, 1793.

Hørlyk, Lucie. Under Tropesol. Copenhagen: Det Schönbergske Forlag, 1907.

Hørlyk, Lucie. Fra Generalguvernørens Dage. Copenhagen: Det Schönbergske Forlag, 1908. 
Hørlyk, Lucie. Den gamle Plantage. Copenhagen: Det Schönbergske Forlag, 1909.

King, Betty L. "Historical Overview of the St. Thomas Reformed Church." In Equipping the Saints: The Synod of New York 180o-200o. Ed. James Hart Brumm. Grand Rapids: Wm. B. Eerdman, 2000, 54-69.

Knox, John P. A Historical Account of St. Thomas, W.I. New York: Charles Scribner, 1852. Mirzoeff, Nicholas. The Right to Look: A Counterhistory of Visuality. Durham: Duke UP, 2011.

Olwig, Karen Fog. "Narrating deglobalization: Danish perceptions of a lost empire." Global Networks 3 (2003), 207-222.

Onana, Marie Biloa. Der Sklavenaufstand von Haiti: Ethnische Differenz und Geschlecht in der Literatur des 19. Jahrhunderts. Köln: Böhlau Verlag Köln, 2010.

Pram, Chresten. Negeren. Copenhagen, 1791.

Riis, Thomas. "Lucie Hørlyk, en dansk vestindisk forfatter." Magasin fra Det kongelige Bibliotek 27:2 (2014), 23-30

Roemer, Kenneth M. The Obsolete Necessity. America in Utopian Writings, 1888-190o. Kent: Kent State UP, 1976.

Scott, Rebecca J. and Jean M. Hébrard. Freedom Papers: An Atlantic Odyssey in the Age of Emancipation. Cambridge: Harvard UP, 2014.

Sixto, Adolph. Time and I, or Looking Forward. San Juan: San Juan News \& Power Print, 1902 (ca.).

Slaughter, Joseph R. "World Literature as Property." Alif:Journal of Comparative Poetics 34 (2014), 39-73.

Sollors, Werner. Neither Black Nor White Yet Both: Thematic Explorations of Interracial Literature. Oxford: Oxford Scholarship Online, 2011.

Spivak, Gayatri Chakravorty. A Critique of Postcolonial Reason. Cambridge: Harvard UP, 1999.

Tansill, Charles C. The Purchase of the Danish West Indies. Baltimore: Johns Hopkins UP, 1932.

Thaarup, Thomas. Peters Bryllup. Copenhagen: Johan Frederik Schultz, 1793.

Thornber, Karen. "Why (Not) World Literature: Challenges and Opportunities for the Twenty-First Century." Journal of World Literature 1:1 (2016), 107-18.

Trollope, Anthony. The West Indies and the Spanish Main. London: Chapman and Hall, 1859 .

Vollquartz, Ingeborg. Glade Barndomsdage i Vestindien. Helsingør: Jens Møllers Forlag, 1903.

Vraa, Mich. Haabet. Copenhagen: Lindhardt \& Ringhof, 2016.

WReC-Warwick Research Collective. Combined and Uneven Development: Towards a New Theory of World-Literature, Liverpool: Liverpool UP, 2015. 